\title{
Overexpression of mitochondrial FAD-linked glycerol-3-phosphate dehydrogenase does not correct glucose-stimulated insulin secretion from diabetic GK rat pancreatic islets
}

\author{
K. Ueda ${ }^{1}$, Y.Tanizawa ${ }^{1}$, H. Ishihara ${ }^{2}$, N. Kizuki ${ }^{1}$, Y.Ohta ${ }^{1}$, A.Matsutani ${ }^{1}$, Y.Oka ${ }^{1}$ \\ ${ }^{1}$ Third Department of Internal Medicine, Yamaguchi University, School of Medicine, Kogushi, Ube, Yamaguchi, Japan \\ ${ }^{2}$ Third Department of Internal Medicine, University of Tokyo, School of Medicine, Hongo, Bunkyo-ku, Tokyo, Japan
}

\begin{abstract}
Summary Glucose-stimulated insulin secretion is impaired in GK (Goto-Kakizaki) rats, perhaps because of abnormalities in glucose metabolism in pancreatic islet beta cells. The glycerol phosphate shuttle plays a major role in glucose metabolism by reoxidizing cytosolic NADH generated by glycolysis. In the pancreatic islets of GK rats, the activity of mitochondrial FAD-linked glycerol-3-phosphate dehydrogenase (mGPDH), the key enzyme of the glycerol phosphate shuttle, is decreased and this abnormality may be responsible, at least in part, for impaired glucose-stimulated insulin secretion. To investigate this possibility, we overexpressed mGPDH in islets isolated from GK rats via recombinant adenovirus-mediated gene transduction, and examined glucose-stimulated insulin secretion. In islets isolated from diabetic GK rats at 8 to 10 weeks of age, glucose-stimulated insulin secretion was severely impaired, and mGPDH activity was decreased to $79 \%$ of that in non-diabetic Wistar rats. When mGPDH was overexpressed in islets from GK rats, enzyme activity and protein content in-
\end{abstract}

creased 2- and 6-fold, respectively. Basal $(3 \mathrm{mmol} / \mathrm{l}$ glucose) and glucose-stimulated $(20 \mathrm{mmol} / \mathrm{l})$ insulin secretion from the Adex1CAlacZ-infected GK rat islets were, respectively, $4.4 \pm 0.7$ and $8.1 \pm 0.7 \mathrm{ng}$. islet $^{-1} \cdot 30 \mathrm{~min}^{-1}$, and those from $\mathrm{mGPDH}$-overexpressed GK rat islets $4.7 \pm 0.3$ and $9.1 \pm 0.8 \mathrm{ng}$. islet $^{-1} \cdot 30 \mathrm{~min}^{-1}$, in contrast to those from the Adex1CAlacZ-infected non-diabetic Wistar rat islets $(4.7 \pm$ 1.6 and $47.6 \pm 11.9 \mathrm{ng} \cdot$ islet $^{-1} \cdot 30 \mathrm{~min}^{-1}$ ). Thus, glucose-stimulated insulin secretion is severely impaired in GK rats even in the stage when $\mathrm{mGPDH}$ activity is modestly decreased, and at this stage, overexpression of $\mathrm{mGPDH}$ cannot restore glucose-stimulated insulin secretion. We conclude that decreased mGPDH activity in GK rat islets is not the defect primarily responsible for impaired glucose-stimulated insulin secretion. [Diabetologia (1998) 41: 649-653]

Keywords FAD-linked glycerol-3-phosphate dehydrogenase, GK rat, non-insulin-dependent diabetes mellitus, insulin secretion, adenovirus
In the GK (Goto-Kakizaki) rat, a spontaneous diabetic rodent model produced by repeated selective breeding of the Wistar rat, the insulin secretory re-

Received: 20 October 1997 and in revised form: 22 December 1997

Corresponding author: Dr. Y.Oka, MD, PhD, Third Department of Internal Medicine, Yamaguchi University School of Medicine, 1144 Kogushi, Ube, Yamaguchi 755-8505 Japan Abbreviations: NIDDM, Non-insulin-dependent diabetes mellitus; mGPDH, mitochondrial FAD-linked glycerol-3-phosphate dehydrogenase; PBS, phosphate-buffered saline; KRB, Krebs-Ringer bicarbonate; Xgal, 5-bromo-4-chloro-2-indolyl beta-D-galactopyranoside. sponse to glucose is selectively impaired $[1,2]$ as in human non-insulin-dependent diabetes mellitus (NIDDM) patients [3]. Because the defect is specific for glucose-stimulated insulin secretion, the metabolic glucose signal appears to be impaired $[4,5]$. Glucose must enter beta cells and be metabolized via glycolytic and mitochondrial oxidative pathways in order to stimulate insulin release. The resulting changes in the intracellular ATP/ADP ratio close the ATP dependent potassium channel (K-ATP), leading to membrane depolarization, $\mathrm{Ca}^{2+}$ entry and insulin exocytosis. In GK rats, it was suggested that the step responsible for the metabolic dysfunction of beta cells is located within the glycolytic pathway before 
glyceraldehyde-3-phosphate or in the glycerol phosphate shuttle $[6,7]$. The glycerol phosphate shuttle interconverts L-glycerol phosphate and dihydroxyacetone phosphate to transfer reducing equivalents into the mitochondrial electron transport chain and reoxidize cytosolic NADH generated from glycolysis.

Mitochondrial FAD-linked glycerol-3-phosphate dehydrogenase (mGPDH, EC 1.1.99.5) is the key enzyme of the glycerol phosphate shuttle. The activity of this enzyme is especially high in the pancreatic islets of rodents [8,9] and humans [10], suggesting the importance of this enzyme in insulin secretory tissue. The activity of mGPDH has been shown to be decreased in the islets of GK rats [11], as well as in those of other rodent models of NIDDM, such as rats injected with streptozotocin in the neonatal period [12], db/db mice [13] and fa/fa rats [14], and in humans [15]. These lines of evidence suggest that decreased mGPDH activity and the resultant decrease in glycerol phosphate shuttle activity may be responsible, at least in part, for the impaired insulin secretion in both the animal models and human NIDDM. Recently, it was reported that insulin treatment of GK rats normalized islet mGPDH activity [16], suggesting that decreased mGPDH enzyme activity in GK rats is secondary to a diabetic syndrome, rather than the primary genetic defect. However, the insulin secretory response after the enzyme activity had returned to normal was not examined in that study and it is still not known whether this decreased enzyme activity is responsible, to some extent, for the altered insulin secretion. To examine these issues, we investigated whether correction of low mGPDH activity improved the impaired glucose-stimulated insulin secretion from isolated GK rat islets, by overexpressing $\mathrm{mGPDH}$ using recombinant adenovirus-mediated gene transduction.

\section{Materials and methods}

Animals. Diabetic GK rats were obtained from the original colony established by Goto and Kakizaki (Tohoku University, Sendai, Japan), and bred and housed locally at Yamaguchi University Medical School Animal Centre. Non-diabetic male Wistar rats were obtained from a commercial breeder (SLC, Hamamatsu, Japan) at the age of 7 weeks and housed locally until the experiments. All rats were given free access to food (a commercial pelleted chow, MF, KBT Oriental, Tokyo, Japan) and water. The experiments were conducted using male rats at 8 to 10 , but mainly at 9 , weeks of age. At this age, the GK rats were significantly more hyperglycaemic in the nonfasting state than were non-diabetic Wistar rats $(17.0 \pm$ $3.9 \mathrm{mmol} / \mathrm{l}, n=8$ vs $8.3 \pm 1.2 \mathrm{mmol} / 1, n=12, p=0.0001$, Mann Whitney U test). Neither weight $(247.5 \pm 1.51 \mathrm{~g}$ vs $233.3 \pm$ $18.9 \mathrm{~g}, p=0.0979)$ nor non-fasting plasma insulin levels $(4.0 \pm$ $3.1 \mathrm{ng} / \mathrm{ml}$ vs $4.0 \pm 4.0 \mathrm{ng} / \mathrm{ml}, p=0.8395$, Mann Whitney U test) differed between the GK and Wistar rats at this age. We used a few female GK rats for the mGPDH enzyme assay, due to a lack of male rats. Although female GK rats weighed slightly less than their male counterparts of the same age, neither blood glucose nor plasma insulin levels differed from those of male GK rats (data not shown).

Measurements of glucose and insulin concentrations. The blood glucose concentration was measured by the glucose oxidase method using a glucose analyzer (Toecho Super, Kyoto Daiichi Kagaku, Kyoto, Japan); insulin by radioimmunoassay using a antibody against guinea pig insulin, human $\left[{ }^{125} \mathrm{I}\right]$ insulin as a tracer, and rat insulin as a standard.

Islet isolation and adenovirus-mediated gene transduction. Pancreatic islets were isolated by collagenase digestion as described previously [17]. Isolated islets were cultured on a $60 \mathrm{~mm}$ tissue culture dish using RPMI-1640 medium containing $11 \mathrm{mmol} / \mathrm{l}$ glucose, supplemented with $10 \%$ fetal calf serum, $100 \mu \mathrm{g} / \mathrm{ml}$ penicillin and $0.1 \mathrm{mg} / \mathrm{ml}$ streptomycin and maintained at $37{ }^{\circ} \mathrm{C}$ in humidified $5 \% \mathrm{CO}_{2}$ and $95 \%$ air. Groups of $50 \sim 100$ islets were incubated with the recombinant adenoviruses at a multiplicity of infection of approximately $4 \times 10^{5}$ pfu/islet. Recombinant adenoviruses containing rat $\mathrm{mGPDH}$ and Escherichia coli lacZ cDNAs were used in the present study. They had previously been constructed and termed Adex1CAmGPDH and Adex1CAlacZ, respectively [18]. Titres of the recombinant adenovirus stocks were $1.1 \times 10^{8} \mathrm{pfu} /$ $\mathrm{ml}$ (Adex1CAmGPDH) and $1.2 \times 10^{7} \mathrm{pfu} / \mathrm{ml}$ (Adex1CAlacZ). After incubation for $1 \mathrm{~h}$ with the adenovirus at $37^{\circ} \mathrm{C}$, the medium was removed and islets were washed once with phosphatebuffered saline (PBS). Islets were then incubated on a $60 \mathrm{~mm}$ tissue culture dish with RPMI-1640 medium. The experiments were performed $24 \mathrm{~h}$ post-infection.

The efficiency of adenovirus-mediated gene transduction into the islets was determined by staining the islets with 5-bromo-4-chloro-2-indolyl beta-D-galactopyranoside (Xgal). After being infected with Adex1CAlacZ, islets were fixed in $0.5 \%$ glutaraldehyde in PBS for 20 min and then washed once with PBS. Expression of $\beta$-galactosidase was demonstrated by staining the fixed islets at $37^{\circ} \mathrm{C}$ for $30 \mathrm{~min}$ in PBS containing $1 \mathrm{mg} / \mathrm{ml}$ of Xgal.

$m G P D H$ enzyme activity. For the measurement of mGPDH enzyme activity in islets, $50 \sim 100$ islets were suspended in $100 \mu \mathrm{l}$ of $\mathrm{N}$-2-hydroxyethylpiperazine- $\mathrm{N}^{\prime}$-2-ethanesulfonic acid (HEPES) buffer ( $5 \mathrm{mmol} / \mathrm{l}, \mathrm{pH} 7.5)$ containing $70 \mathrm{mmol} / \mathrm{l}$ sucrose, $230 \mathrm{mmol} / 1 \mathrm{mannitol}, 15 \mathrm{mmol} / \mathrm{l} \mathrm{KCl}$ and $3 \mathrm{mmol} / \mathrm{l}$ $\mathrm{KH}_{2} \mathrm{PO}_{4}$ and sonicated 30 times in $30 \mathrm{~s}$ with a $0.5 \mathrm{~s}$ pulse sonication at an output level of 7 using a Sonifier Cell Disrupter W200P (Heat Systems-Ultrasonics, Inc. Plainview, N.Y. USA). After brief centrifugation with a microcentrifuge, the supernatants were saved. The protein concentration was determined by Lowry's method, and aliquots containing $100 \mu \mathrm{g}$ protein were used for the enzyme assay. We measured the activity of mGPDH enzyme using a previously described colourimetric assay [16]. Islet extracts containing $40 \mu \mathrm{g}$ protein were incubated in $200 \mu \mathrm{l}$ of $50 \mathrm{mmol} / \mathrm{l} \mathrm{BICINE}$ buffer (Sigma, St. Louis, Mo. USA) pH 8.0, containing $50 \mathrm{mmol} / \mathrm{l} \mathrm{D,} \mathrm{L- \alpha -glyceropho-}$ sphate, $4 \mathrm{mmol} / \mathrm{l}$ Iodonitrotetrazolium Violet (INT, Sigma), $1 \mathrm{mmol} / \mathrm{l} \mathrm{KCN}$, at $37^{\circ} \mathrm{C}$ for $30 \mathrm{~min}$. The reaction was stopped by adding $1 \mathrm{ml}$ of ethylacetate and the ethylacetate layer was separated from the aqueous layer by centrifugation for $3 \mathrm{~min}$. The reduced INT in the ethylacetate extract was quantitated spectrophotometrically by measuring absorbance at $490 \mathrm{~nm}$.

Western blotting. The amount of mGPDH protein was estimated by Western blotting. Anti-mouse mGPDH rabbit antiserum was raised against a synthetic peptide derived from the carboxyl terminus of mouse mGPDH (LDR RVP IPV DRS CGG). 
The antibody was purified as described previously [19]. Immuno-detection was performed using a SuperSignal CL-HRP Substrate System (Pierce, Rockford, Ill. USA). The intensities of the mGPDH bands were quantified using a Molecular Imager (Bio-Rad).

Measurement of insulin secretion. We preincubated ten islets, $24 \mathrm{~h}$ after the infection with recombinant adenoviruses, for $30 \mathrm{~min}$ in $500 \mu \mathrm{l}$ of Krebs-Ringer bicarbonate (KRB) buffer with $3 \mathrm{mmol} / 1$ glucose. Islets were then further incubated in $500 \mu \mathrm{l}$ of KRB buffer containing $3 \mathrm{mmol} / \mathrm{l}$ or $20 \mathrm{mmol} / \mathrm{l}$ glucose at $37^{\circ} \mathrm{C}$ for $30 \mathrm{~min}$ in $5 \% \mathrm{CO}_{2}$ and $95 \% \mathrm{O}_{2}$. Aliquots of the incubation buffer were used for radioimmunoassay of insulin.

Statistical analysis. Data are presented as means \pm SEM. The statistical significance of differences between mean values was assessed using the unpaired-Student's $t$ test. For the data not distributed normally, we used the Mann Whitney U test, as indicated after the $p$-values.

\section{Results}

The GK rats were overtly diabetic at 9 weeks of age $(17.0 \pm 3.9 \mathrm{mmol} / \mathrm{l})$. At this age, the $\mathrm{mGPDH}$ enzyme activity of GK rat islets was decreased to $79 \%$ of that of non-diabetic Wistar rat islets (GK rat: $1.40 \mathrm{nmol} \cdot \mathrm{min}^{-1} \cdot \mathrm{mg}$ protein ${ }^{-1}$ vs Wistar rat: $1.78 \mathrm{nmol} \cdot \mathrm{min}^{-1} \cdot \mathrm{mg}$ protein $\left.{ }^{-1}\right)($ Table 1$)$. Expression of the mGPDH protein was also examined by Western blot analysis. The amount of $\mathrm{mGPDH}$ protein, as determined by Western blotting, did not differ between the GK and the control Wistar rats (Fig. 1).

We tested whether the impairment of glucose-stimulated insulin secretion was due to decreased mGPDH activity in the islets by overexpressing mGPDH using adenovirus-mediated gene transduction. First, we examined the efficiency and toxicity of adenovirus infection of isolated islets using a recombinant adenovirus containing the E. coli lac Z gene (Adex1CAlacZ). When the islets were stained with Xgal $24 \mathrm{~h}$ after infection, intense blue staining was observed in all of the islets (Fig. 2A). No blue staining with Xgal was observed in untreated islets (Fig. 2B). There were no apparent post-infection changes in either the numbers or the morphological features of the islets.

Next, GK rat islets were infected with Adex1CAmGPDH. The mGPDH activity increased approximately twofold $\left(2.59 \mathrm{nmol} \cdot \mathrm{min}^{-1} \cdot \mathrm{mg}\right.$ protein $^{-1}$ ) as compared with uninfected or Adex1CAlacZ-infected GK rat islets $\left(1.40 \mathrm{nmol} \cdot \mathrm{min}^{-1} \cdot \mathrm{mg}\right.$ protein $^{-1}$ and $1.27 \mathrm{nmol} \cdot \mathrm{min}^{-1} \cdot \mathrm{mg}$ protein ${ }^{-1}$, respectively) (Table 1). The mGPDH protein increased by sixfold, as assessed by the Western blot analysis (Fig.1). Adenovirus infection itself changed neither mGPDH activity (Table 1) nor the protein level (Fig. 1 and data not shown), based on the data obtained by Adex1CAlacZ infection.
Table 1. Enzyme activity of $\mathrm{mGPDH}\left(\mathrm{nmol} \cdot \mathrm{min}^{-1} \cdot \mathrm{mg}^{-1}\right.$ protein)

\begin{tabular}{llllr}
\hline & Study 1 & Study 2 & Mean & $\%$ \\
\hline Wistar & 1.79 & 1.77 & 1.78 & 100 \\
GK & 1.36 & 1.43 & 1.40 & 79 \\
GK LacZ & 1.02 & 1.51 & 1.27 & 71 \\
GK mGPDH & 2.10 & 3.09 & 2.59 & 154 \\
\hline
\end{tabular}

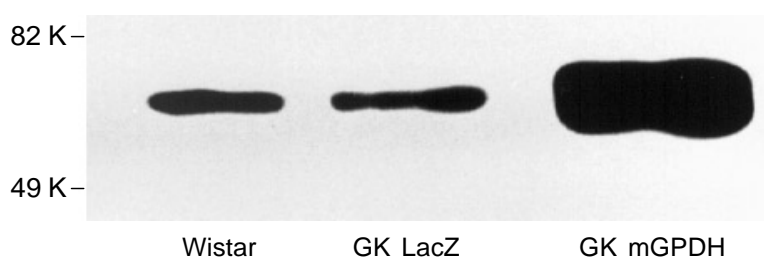

Fig. 1. Western blotting of islet homogenates for mGPDH. Each lane contained $10 \mu \mathrm{g}$ of protein. Wistar: uninfected Wistar rat islets, GK LacZ: GK rat islets infected with Adex1CALacZ, GK mGPDH: GK rat islets infected with Adex1CAmGPDH
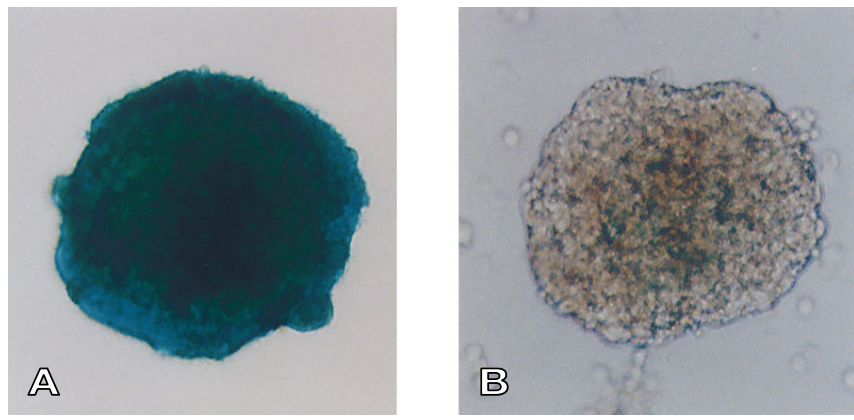

Fig. 2 A, B. Expression of $\beta$-galactosidase in an islet infected with Adex1CAlacZ. A Light microscopic view of a representative islet $24 \mathrm{~h}$ after infection with Adex1CALacZ. B A control uninfected islet similarly treated with a chromogenic substrate is also shown. Magnification is $\times 600$

Glucose-stimulated insulin secretion was then examined. Adenovirus infection did not affect insulin secretion from Wistar rat islets at the basel $(3 \mathrm{mmol} /$ 1) glucose concentration, $4.9 \pm 0.1 \mathrm{ng} \cdot$ islet $^{-1}$. $30 \mathrm{~min}^{-1}$ in uninfected islets compared with $4.7 \pm$ $1.6 \mathrm{ng} \cdot$ islet $^{-1} \cdot 30 \mathrm{~min}^{-1}$ in Adex1CAlacZ-infected islets $(p=0.700, n=3$, Mann Whitney $\mathrm{U}$ test $)$, or at $20 \mathrm{mmol} / 1$ glucose $(50.5 \pm 7.4$ vs $47.6 \pm 11.9, p=$ $0.806, n=3$ ) (Fig. 3). Neither did Adex1CAlacZ infection affect insulin secretion from GK rat islets (Fig. 3 and data not shown). Insulin secretion at the basal glucose concentration $(3 \mathrm{mmol} / \mathrm{l})$ from the Adex1CAlacZ-infected GK rat islets $(4.1 \pm 0.4 \mathrm{ng}$. islet $^{-1} \cdot 30 \mathrm{~min}^{-1}$ ) did not differ from that from the Adex1CAlacZ-infected control non-diabetic Wistar rat islets $\left(4.7 \pm 1.6 \mathrm{ng} \cdot\right.$ islet $^{-1} \cdot 30 \mathrm{~min}^{-1}, \quad p=0.697$, $n=3)$. However, glucose-stimulated $(20 \mathrm{mmol} / \mathrm{l})$ insulin secretion from the Adex1CAlacZ-infected GK rats islets was severely impaired $(7.5 \pm 0.9)$ as com- 


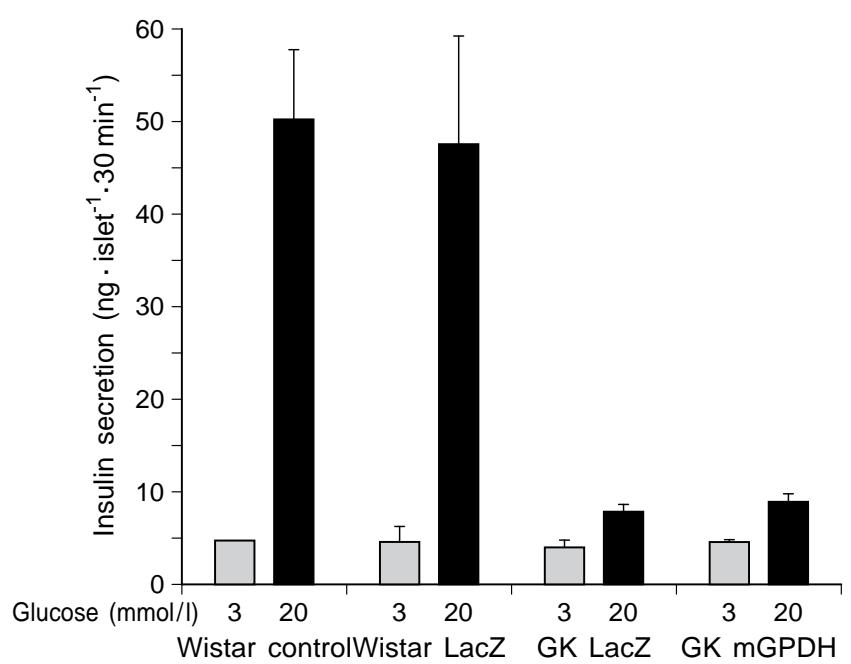

Fig. 3. Insulin secretion from islets at $3 \mathrm{mmol} / 1$ and $20 \mathrm{mmol} / 1$ glucose. Data represent mean \pm SEM of three independent experiments. Wistar: uninfected Wistar rat islets, Wistar LacZ: Wistar rat islets infected with Adex1CALacZ, GK LacZ: GK rat islets infected with Adex1CALacZ, GK mGPDH: GK rat islets infected with Adex1CAmGPDH

pared with that from Adex1CAlacZ-infected Wistar rat islets $(47.6 \pm 11.9, p=0.036, n=3$, Mann Whitney U test) (Fig. 3).

Overexpression of $\mathrm{mGPDH}$ in GK rat islets did not change basal insulin secretion $(4.6 \pm 0.2 \mathrm{ng}$. islet $^{-1} \cdot 30 \mathrm{~min}^{-1}$ vs $4.1 \pm 0.4 \mathrm{ng} \cdot$ islet $^{-1} \cdot 30 \mathrm{~min}^{-1}, p=$ $0.384, n=3$ ). Contrary to our expectation, overexpression of $\mathrm{mGPDH}$ did not improve glucose-stimulated insulin secretion $\left(8.7 \pm 1.1 \mathrm{ng} \cdot\right.$ islet $^{-1} \cdot 30 \mathrm{~min}^{-1}$ vs $7.5 \pm 0.9$ in Adex1CAlacZ-infected GK rat islets, $p=0.420, n=3$ ) (Fig.3) despite mGPDH activity and the protein level having been corrected to levels higher than those in normal Wistar rat islets (Table 1, Fig. 1).

\section{Discussion}

In our local colony, GK rats developed diabetes mellitus by 8 weeks of age. Glucose-stimulated insulin secretion from isolated GK rat islets was severely impaired as compared with that from islets of non-diabetic Wistar rats of the same age. The mGPDH activity in GK rat islets decreased to $79 \%$ of that in islets from control Wistar rats at 9 weeks of age.

To determine whether low islet mGPDH activity contributes to the impaired glucose-stimulated insulin secretion in GK rats, we endeavoured to correct decreased mGPDH activity using adenovirus-mediated gene transduction. The efficiency of gene transfer to the islets was very high (nearly $100 \%$ ), as demonstrated by bacterial lac $Z$ gene transduction, as previously reported by Becker et al. [20]. Using this system, we were able to overexpress $\mathrm{mGPDH}$ in GK rat islets. We could correct mGPDH enzyme activity and the protein level, both of which were higher than the levels observed in control Wistar rat islets. However, this increase in mGPDH activity did not restore glucose-stimulated insulin secretion in GK rat islets. Adenovirus infection itself did not appear to be toxic to islet cells under our experimental conditions because Adex1CAlacZ infection had no effect on either basal or stimulated insulin secretion in both GK and Wistar rat islets. One possibility is that the overexpressed mGPDH was not targeted to the mitochondria of GK rat islet beta cells. Although we did not test this possibility directly in GK rat islets, it is unlikely based on the following observations. We were able to efficiently transfer the gene to nearly $100 \%$ of islet cells (Fig. 2A), the great majority of which were beta cells. In addition, we have demonstrated previously that overexpression of mGPDH using the same adenovirus vector system increased enzyme activity in the mitochondrial fraction, thereby increasing glycerol phosphate shuttle flux in cultured beta cell lines [18].

The impaired glucose-stimulated insulin secretion observed in GK rats has been suggested to be attributable, at least in part, to a concomitant decrease in mGPDH activity which leads to decreased glycerol phosphate shuttle activity $[4,11]$. Although the decrease in mGPDH activity was modest $(79 \%$ of control) in our GK rats, it is still possible that the decreased activity would explain, at least in part, the severely impaired insulin secretion, given that glycerol phosphate shuttle activity is one of the key steps in glucose metabolism in beta cells, and thus in glucosestimulated insulin secretion. However, our results suggest that this is not the case, at least in GK rats at the stage of diabetes employed in the present study. Glucose-stimulated insulin secretion was not restored by overexpression of mGPDH. This result strongly suggests that decreased mGPDH activity is not a primary defect causing impaired glucose-stimulated insulin secretion in GK rats. Consistent with this, it was recently reported that the decreased enzyme activity returned to normal after insulin treatment of GK rats, suggesting that decreased mGPDH activity in GK rat islets is secondary to a diabetic phenomenon [16].

In the present study, although glucose-stimulated insulin secretion was severely impaired at 9 weeks of age, the decrease in mGPDH activity was modest and the amount of mGPDH protein was essentially unchanged. These observations are in contrast to those in previous reports in which enzyme activity and the mGPDH protein level decreased to 30-40\% of those in control Wistar rats $[11,16]$. This may be due to differences in genetic or environmental conditions (e.g. colony, age, food, etc.). The mGPDH activity and protein might have decreased further in our colony had the rats been allowed to grow older. 
Under conditions of even more profoundly decreased mGPDH activity, our results do not exclude the possibility that decreased mGPDH activity contributes to impaired glucose-stimulated insulin secretion.

In conclusion, decreased mGPDH activity in GK rat islets is not a primary defect causing impaired glucose-stimulated insulin secretion, and restoration of enzyme activity is not sufficient to restore insulin secretion, at least in the early stage of diabetes in GK rats.

Acknowledgements. We thank Dr. S. Suzuki (Tohoku University, School of Medicine, Sendai, Japan) for providing GK rats, and Drs. Y. Yamaguchi, T.Murata and staff members of the Animal Centre of Yamaguchi University School of Medicine for their help in breeding and housing GK rats. This work was supported by a grant from Uehara Memorial Foundation (to YO) and Grant-in-Aid for scientific Research (A2) (09357009 to $\mathrm{YO})$.

\section{References}

1. Goto Y, Kakizaki M, Masaki N (1975) Spontaneous diabetes produced by selective breeding of normal Wistar rats. Proceedings of the Japan Academy. 51: 80-85

2. Portha B, Serradas P, Bailbe D, Suzuki K, Goto Y, Giroix M-H (1991) Beta cell insensitivity to glucose in the GK rat, a spontaneous nonobese model for type II diabetes. Diabetes 40: 486-491

3. Ward WK, Beard JC, Halter JB, Pfeiffer MA, Porte D (1984) Pathophysiology of insulin secretion in non-insulin dependent diabetes mellitus. Diabetes Care 7: 491-502

4. Östenson C-G, Khan A, Abdel-Halim SM, Guenifi A, Suzuki K, Goto Y, Efendic S (1993) Abnormal insulin secretion and glucose metabolism in pancreatic islets from the spontaneously diabetic GK rat. Diabetologia 36: 3-8

5. Hughes SJ, Suzuki K, Goto Y (1994) The role of islet secretory function in the development of diabetes in the GK Wistar rat. Diabetologia 37: 863-870

6. Ohneda M, Johnson JH, Inman LR et al. (1993) GLUT2 expression and function in beta-cells of GK rats with NIDDM. Diabetes 42: 1065-1072

7. Tsuura Y, Ishida H, Okamoto Y et al. (1993) Glucose sensitivity of ATP-sensitive $\mathrm{K}$ channels is impaired in beta-cells of the GK rat. A new genetic model of NIDDM. Diabetes 42: $1446-1453$
8. MacDonald MJ (1981) High content of mitochondrial glycerol 3-phosphate dehydrogenase in pancreatic islets and its inhibition by diazoxide. J Biol Chem 256: 8287-8290

9. Meglasson MD, Smith KM, Nelson D, Erecinski M (1989) $\alpha$-glycerophosphate shuttle in a clonal $\beta$-cell line. Am J Physiol 256: E173-E178

10. MacDonald MJ, Warner TF, Pellet JR (1983) Increased mitochondrial glycerol phosphate dehydrogenase activity in insulinomas of two hypoglycemic infants. J Clin Endocrinol Metab 57: 662-664

11. Östenson CG, Abdel-Halim SM, Rasschaert J et al. (1993) Deficient activity of FAD-linked glycerolphosphate dehydrogenase in islets of GK rats. Diabetologia 36: 722-726

12. Giroix M-H, Rasschaert J, Bailbe D, Leclercq-Meyer V, Sener A, Portha B, Malaisse WJ (1991) Impairment of glycerol phosphate shuttle in islets from rats with diabetes induced by neonatal streptozotocin. Diabetes 40: 227-232

13. Sener A, Herberg L, Malaisse WJ (1993) FAD-linked glycerophosphate dehydrogenase deficiency in pancreatic islets of mice with hereditary diabetes. FEBS Lett 316: 224-227

14. Rasschaert J, Malaisse-Lagae F, Sener A, Leclercq-Meyer V, Herberg L, Malaisse WJ (1994) Impaired FAD-glycerophosphate dehydrogenase activity in islet and liver homogenates of fa/fa rats. Mol Cell Biochem 135: 137-141

15. Fernandez-Alvarez J, Conget I, Rasschaert J, Sener A, Gomis R, Malaisse WJ (1994) Enzymatic, metabolic and secretory patterns in human islets of type 2 (non-insulin dependent) diabetic patients. Diabetologia 37: 177-181

16. MacDonald MJ, Efendic S, Östenson C-G (1996) Normalization by insulin treatment of low mitochondrial glycerol phosphate dehydrogenase and pyruvate carboxylase in pancreatic islets of the GK rat. Diabetes 45: 886-890

17. Lacy P, Kostianovsky M (1967) Method for the isolation of intact islets of Langerhans from the rat pancreas. Diabetes 16: $35-39$

18. Ishihara H, Nakazaki M, Kanegae Y et al. (1996) Effect of mitochondrial and/or cytosolic glycerol 3-phosphate dehydrogenase overexpression on glucose-stimulated insulin secretion from MIN6 and HIT cells. Diabetes 45: 1238-1244

19. Oka Y, Asano T, Shibasaki Y, Kasuga M, Kanazawa Y, Takaku F (1988) Studies with antipeptide antibody suggest the presence of at least two types of glucose transporter in rat brain and adipocyte. J Biol Chem 263: 13432-13439

20. Becker TC, Beltrandelrio H, Noel RJ, Johnson JH, Newgard CB (1994) Overexpression of hexokinase I in isolated islets of Langerhans via recombinant adenovirus. J Biol Chem 269: 21234-21238 